\title{
Prospects for the Disposal of By-Products from the Processing of Aquatic Biological Resources
}

\author{
Svetlana Maksimova ${ }^{1 *}$, Denis Poleshchuk ${ }^{1}$, Svetlana Ponomarenko ${ }^{1}$, Aleksandr Bashtovoy ${ }^{1}$ \\ and Ekaterina Shadrina ${ }^{1}$ \\ ${ }^{1}$ Far Eastern State Technical Fisheries University, Engineering Disciplines Department, 52 B \\ Lugovaya Str., Vladivostok 690087, Russia
}

\begin{abstract}
The expediency of using waste generated during industrial processing of commercial aquatic biological resources is justified. Byproducts obtained as a result of cutting fish and non-fish objects represent a significant source of biologically valuable substances. The article provides information on the use of secondary raw materials for the production of feed products for farm animals, birds and aquaculture facilities for the production of biologically valuable products, biofuels. The paper presents an assessment of the technological potential of by-products formed during the processing of the most profitable commercial objects - crabs and salmon. Such bu-products include carapace of the cephalothorax, crab entrails, as well as the caviar film remaining during the punching of salmon fish hawks. The assessment of the total chemical composition of the waste from the cutting of the blue crab was carried out. The high biological value of the hepatopancreas and carapace crab proteins was revealed. The general chemical waste from punching of chum salmon hawks is given. The high biological value of these waste lipids was confirmed by evaluating their fatty acid composition. The possibility and necessity of using the studied waste for the production of biologically valuable products is experimentally justified.
\end{abstract}

\section{Introduction}

According to FAO data by 2030 , the total volume of aquatic biological resources caught and grown under aquaculture conditions will amount to 200 million tons. An increase in the processing of aquatic biological resources inevitably leads to an increase in the amount of by-products, which in some cases can reach $70 \%$ of the mass of raw materials. Such products include waste generated during the processing of aquatic biological resources: heads, viscera, skin, bones, scales, crustacean shells, etc. Most of these by-products are thrown away as waste. Recently, this problem of the development and implementation of complex and wastefree technologies has attracted the attention of scientists, since by-products are a significant source of biologically valuable substances and can be considered as secondary raw materials for the production of food and feed products [1].

\footnotetext{
*Corresponding author: maksimova.sn@dgtru.ru
} 
Most often, by-products from the cutting of aquatic biological resources are used to obtain feed products for farm animals, birds and aquaculture facilities [2-5]

By-products obtained from the processing of aquatic biological resources serve as raw materials for the production of biofuels and biogas [6-10], as well as for obtaining collagen [11-15]

By-products formed during the cutting of aquatic biological resources are processed by the method of enzymatic hydrolysis to obtain valuable biologically valuable products [16$18]$.

Various uses of by-products obtained during the processing of aquatic biological resources are determined by their significant technological potential, which is estimated by the general chemical composition, as well as the biological value of proteins, lipids, etc.

Thus, it is precisely the determination of the technological potential of secondary raw materials from processing of aquatic biological resources is an important task in determining the prospects for its rational use.

Among aquatic biological resources, crabs and salmon fish are among the most profitable processing facilities.

When processing crabs, the share of by-products is about $80 \%$; these include cephalothorax carapace, films, viscera (including the liver). In most cases, this waste is not sorted, accumulated or processed, but disposed of by dumping into the sea. If waste is discharged in one area in large quantities, deterioration of the sanitary and hygienic state of this water area may occur.

The problem of ensuring the ecological and sanitary-hygienic cleanliness at the coastal enterprises engaged in the processing of salmon fish in order to obtain salmon caviar is the disposal of the caviar film remaining during the punching of ovaries.

By-products generated during the processing of crabs and salmon are the object of research in order to determine their technological potential to determine the prospects for their further use.

\section{Materials and Methods}

By-products obtained after cutting blue crab (Paralithodes platypus) and punching chum salmon (Oncorhynchus keta) were used as the object of the study.

The determination of protein substances was determined by oxidation of organic substances by burning it in sulfuric acid in the presence of a catalyst, stripping the formed ammonia with steam, trapping it with a sulfuric acid solution and determining the nitrogen content by titration.

The mass fraction of fat was determined by the extraction method in a Soxhlet apparatus. The method is based on the extraction of fat with an organic solvent from a dry sample and the determination of its mass by weighing.

The mass fraction of water was determined by evaporating it from the test sample during heat treatment at a temperature of $100-105^{\circ} \mathrm{C}$ and determining the change in its weight by weighing.

Mineral substances were determined by removing organic substances from a weighed portion of the analyzed sample by burning and determining the resulting ash by weighing.

The composition and quantitative content of amino acids were determined by highperformance liquid chromatography on an automatic amino acid high-speed analyzer L- 8800 (Hitachi , Japan) using a $200 \times 4.6 \mathrm{~mm}$ column, an Ultropac- $8 \mu(\mathrm{Li}+)$ ion exchanger, Licitrate buffers with a $\mathrm{pH}$ of 2.8-3.5, a ninhydrine reagent for development (color reaction at $135^{\circ} \mathrm{C}$ ). The calculation was performed by comparing the peak areas of the studied samples with the peak areas of the standard mixture of amino acids «Sigma (USA)». To determine 
the tryptophan content, the samples were hydrolyzed with barium hydroxide at a temperature of $110^{\circ} \mathrm{C}$ for $18 \mathrm{~h}$.

Fatty acids were determined in the form of their methyl esters on a Shimadzu GC-16A capillary gas-liquid chromatograph (Supelcowax-10) with flame an ionization detector equipped with a capillary column $\left(30.0 \mathrm{~m}^{\prime} 0.3 \mathrm{~mm}\right)$ at a temperature of $190^{\circ} \mathrm{C}$.

\section{Results and Discussion}

Traditionally, the muscle tissues of crabs are used for food, for commercial species, their composition is the main subject of research, which is also true for the blue crab. Despite the fact that the composition of the muscle tissue of this crab has been studied in sufficient detail, however, the non-food parts, such as carapace and hepatopancreas of this type of crab, have not been sufficiently studied, despite the fact that the share of carapace in waste is $37-42 \%$, hepatopancreas - 4-8\% [19].

The total chemical composition of the by-products from the cutting of the blue crab Paralithodes platypus is presented in Table 1.

Table 1. Indicators of the composition of the parts of the blue crab Paralithodes platypus

\begin{tabular}{|c|c|c|c|c|c|}
\hline \multirow{2}{*}{ Body part } & \multicolumn{5}{|c|}{ Mass fraction, \% } \\
\cline { 2 - 6 } & Water & Protein & Lipids & $\begin{array}{c}\text { Mineral } \\
\text { substances }\end{array}$ & Chitin \\
\hline Carapace & $69.49 \pm 1.22$ & $12.96 \pm 0.05$ & $1.20 \pm 0.1$ & $9.82 \pm 0,11$ & $\begin{array}{c}6.53 \pm \\
0.05\end{array}$ \\
\hline Hepatopancreas & $77.33 \pm 1.22$ & $16.80 \pm 0.05$ & $5.41 \pm 0.1$ & $1.71 \pm 0.11$ & - \\
\hline
\end{tabular}

The data presented in Table 1 demonstrate that the carapace and hepatopancreas of the studied blue crab Paralithodes platypus have certain differences in the content of the main substances. Carapace is characterized by a higher content of dry substances (the excess in comparison with hepatopancreas is $34 \%$ ). The protein content in hepatopancreas is $30 \%$ higher than that in carapace. The lipid content shows even more significant differences - in the hepatopancreas they are 4.5 times more. However, minerals show an inverse relationship, they are more in carapace 5.7 times due to the presence of chitin in it.

The qualitative and quantitative amino acid composition of the proteins of the parts of the blue crab Paralithodes platypus is presented in Table 2.

Table 2. Amino acid composition of the proteins of the blue crab parts Paralithodes platypus

\begin{tabular}{|c|c|c|c|c|c|c|}
\hline \multirow{3}{*}{ 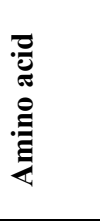 } & \multicolumn{6}{|c|}{ Content } \\
\hline & $\begin{array}{c}\mathrm{mg} / \mathrm{g} \\
\text { weight }\end{array}$ & mg/g protein & $\begin{array}{c}\% \text { of the } \\
\text { amount of } \\
\text { amino } \\
\text { acids } \\
\end{array}$ & $\begin{array}{c}\mathrm{mg} / \mathrm{g} \\
\text { weight }\end{array}$ & mg/g protein & $\begin{array}{c}\% \text { of the } \\
\text { amount of } \\
\text { amino } \\
\text { acids } \\
\end{array}$ \\
\hline & \multicolumn{3}{|c|}{ Hepatopancreas } & \multicolumn{3}{|c|}{ Carapace } \\
\hline \multicolumn{7}{|c|}{ Irreplaceable } \\
\hline Thr & $8.84 \pm 0.41$ & $52.63+2.19$ & $5.26 \pm 0.11$ & $6.39 \pm 0.18$ & $49.32 \pm 2.27$ & $4.93+0.20$ \\
\hline Ile & $7.22 \pm 0.23$ & $43.02 \pm 2.02$ & $4.30 \pm 0.15$ & $5.14 \pm 0.19$ & $39.71 \pm 1.28$ & $3.97 \pm 0.14$ \\
\hline Leu & $11.26 \pm 0.39$ & $67.04+3.04$ & $6.70 \pm 0.27$ & $8.25 \pm 0.30$ & $63.73 \pm 2.79$ & $6.37 \pm 0.26$ \\
\hline Val & $7.83 \pm 0.27$ & $46.64 \pm 1.96$ & $4.66 \pm 0.17$ & $5.61 \pm 0.19$ & $43.33+2.12$ & $4.33+0.17$ \\
\hline Lys & $10.84 \pm 0.36$ & $64.54+3.02$ & $6.45 \pm 0.29$ & $7.77 \pm 0.27$ & $61.23+2.59$ & $6.12+0.29$ \\
\hline Met & $0.83 \pm 0.03$ & $4.97 \pm 0.16$ & $0.50 \pm 0.02$ & $0.40 \pm 0.01$ & $3.09 \pm 0.15$ & $0.30 \pm 0.01$ \\
\hline Phe & $6.55 \pm 0.18$ & $39.00+1.49$ & $3.90 \pm 0.15$ & $4.85 \pm 0.13$ & $37.45+1.57$ & $3.75+0.15$ \\
\hline Trp & $2.70 \pm 0.03$ & $16.06+0.61$ & $1.61 \pm 0.06$ & $2.11 \pm 0.08$ & $16.25+0.58$ & $1.62+0.07$ \\
\hline Total & $56.07 \pm 2.12$ & $333.90 \pm 15.11$ & $33.38 \pm 1.51$ & $40.52 \pm 2.00$ & $314.11 \pm 14.55$ & $31.39 \pm 1.49$ \\
\hline
\end{tabular}




\begin{tabular}{|c|c|c|c|c|c|c|}
\hline \multicolumn{7}{|c|}{ Conditionally-replaceable and replaceable } \\
\hline Tyr & $7.42 \pm 0.27$ & $44,20 \pm 2.00$ & $4.42 \pm 0.18$ & $5.49 \pm 0.12$ & $42.43 \pm 1.85$ & $4.24 \pm 0.21$ \\
\hline Cys & $0.66 \pm 0.01$ & $3.93 \pm 0.11$ & $0.39 \pm 0.00$ & $0.32 \pm 0.00$ & $2.50 \pm 0.10$ & $0.25 \pm 0.00$ \\
\hline His & $3.35 \pm 0.12$ & $19.93 \pm 0.85$ & $1.99 \pm 0.07$ & $3.62 \pm 0.11$ & $27.90 \pm 1.02$ & $2.79 \pm 0.11$ \\
\hline Arg & $8.29 \pm 0.36$ & $63.94 \pm 2.80$ & $6.39 \pm 0.24$ & $8.05 \pm 0.32$ & $62.10 \pm 3.01$ & $6.21 \pm 0.25$ \\
\hline Asp & $16.81 \pm 0.66$ & $100.10 \pm 4.45$ & $10.00 \pm 0.39$ & $13.31 \pm 0.48$ & $102.74 \pm 4.59$ & $10.27 \pm 0.42$ \\
\hline Ser & $7.38 \pm 0=.29$ & $43.95 \pm 1.65$ & $4.40 \pm 0.15$ & $6.16 \pm 0.21$ & $47.59 \pm 2.06$ & $4.76 \pm 0.21$ \\
\hline Glu & $25.50 \pm 1.05$ & $151.80 \pm 6.81$ & $15.18 \pm 0.46$ & $20.01 \pm 0.86$ & $154.44 \pm 6.63$ & $15.44 \pm 0.66$ \\
\hline Pro & $17.08 \pm \underline{ \pm 0.72}$ & $101.71 \pm 4.76$ & $10.17 \pm 0.41$ & $13.52 \pm 0.55$ & $104.37 \pm 5.01$ & $10.44 \pm 0.40$ \\
\hline Gly & $14.17 \pm 0.53$ & $84.39 \pm 3.25$ & $8.44 \pm 0.22$ & $11.27 \pm 0.48$ & $87.03+3.60$ & $8.70 \pm 0.36$ \\
\hline Ala & $8.76 \pm 0.31$ & $52.15 \pm 2.03$ & $5.22 \pm 0.23$ & $7.10 \pm 0.27$ & $54.79 \pm 2.41$ & $5.48 \pm 0.22$ \\
\hline Total & $108.48 \pm 5.01$ & $666.10 \pm 30.15$ & $66.60 \pm 3.01$ & $88.85 \pm 4.05$ & $685.89 \pm 32.04$ & $68.58 \pm 3.02$ \\
\hline In total & $165.49 \pm 6.78$ & 1,00 & $99.98 \pm 4.03$ & $129.37 \pm 4.91$ & 1,00 & $99.97 \pm 4.19$ \\
\hline
\end{tabular}

The analysis of the obtained results shows that the composition of amino acids is identical for carapace and hepatopancreas of the blue crab Paralithodes platypus, but there are some differences in the content of individual representatives. The total amino acid content is 165.49 $\mathrm{mg} / \mathrm{g}$ of weight in hepatopancreas and $129.37 \mathrm{mg} / \mathrm{g}$ of weight in carapace, a difference of $28 \%$. Conditionally-substituted and replaceable amino acids quantitatively significantly predominate over the essential ones, the excess in hepatopancreas is 2 times, in carapace 2.2 times. The content of essential amino acids in hepatopancreas proteins is slightly higher than in carapace and varies from $314.11 \mathrm{mg} / \mathrm{g}$ of protein in carapace to $333.90 \mathrm{mg} / \mathrm{g}$ of protein in hepatopancreas. The common major amino acids for all the studied parts of the blue crab Paralithodes platypus are the amino acids - threonine, leucine, lysine, arginine, glutamic acid, aspartic acid, glycine, proline.

It was found that the main part of the amino acids in the proteins of the studied parts of the blue crab Paralithodes platypus are aliphatic monoaminomonocarboxylic amino acids (28.85-29.32\% of the total amino acids) and monoaminodicarboxylic acids (25.18-25.71\% of the total amino acids), and the total content in carapace and hepatopancreas does not differ much. It is also necessary to note a fairly high content of diaminomonocarboxylic amino acids (12.33-12.84 \% of the total amino acids). The content of aromatic amino acids is 9.61 $9.93 \%$ of the total of amino acids, heterocyclic-12.17-14.85\% of the total of amino acids with a predominance in carapace. Oxymonoaminocarboxylic amino acids are not more than $9.69 \%$ of the total amino acids. The least represented are sulfur-containing amino acids, their content is minimal and does not exceed $0.89 \%$ of the total amino acids.

Of the 18 identified amino acids, 8 are essential, the predominant of which are leucine, lysine, and threonine. This is typical for both carapace and hepatopancreas, but their total content in hepatopancreas is slightly higher than in carapace $(18.41 \%$ vs. $17.42 \%)$. It is necessary to note a fairly high content of two conditionally interchangeable amino acidsarginine and histidine, and the histidine content in carapace is $40 \%$ higher than that in hepatopancreas, the arginine content differs slightly.

Of the substitutable and conditionally substitutable amino acids, 10 representatives were identified. The set of maximally represented interchangeable amino acids is identical for carapace and hepatopancreas. Substituted amino acids are maximally represented by glutamic acid (15.18-15.44 \%) with a slight predominance in carapace, proline (10.17-10.44 $\%$ ) with a slight predominance in carapace, aspartic acid (10.00-10.27\%), glycine (8.44-8.70 $\%)$. The total content of the predominant non-essential amino acids is $44.41-44.85 \%$ with a slight excess in carapace, which is $65.4-66.7 \%$ of the total content of non-essential and conditionally non-essential amino acids.

When processing salmon fish, the most valuable food product is salted caviar. During its production, the joints are punched, as a result of which by-products is formed in the form of connective tissue (film). 
The total chemical composition of by-products from punching the roe of the chum salmon Oncorhynchus keta is presented in Table 3.

Table 3. Indicators of the composition of by-products from punching the roe of the chum salmon

Oncorhynchus keta

\begin{tabular}{|c|c|c|c|c|c|}
\hline \multirow{2}{*}{ Name } & Water & Protein & Lipids & $\begin{array}{c}\text { Mineral } \\
\text { substances }\end{array}$ & Carbohydrates \\
\cline { 2 - 6 } & $79.37 \pm 0.31$ & $9.56 \pm 0.12$ & $4.49 \pm 0.07$ & $1.08 \pm 0.05$ & $5.50 \pm 0.45$ \\
\hline $\begin{array}{c}\text { Roe of } \\
\text { Oncorhynchus } \\
\text { keta }\end{array}$ & & & & & \\
\hline
\end{tabular}

The data presented in Table 3 demonstrate that the roe of Oncorhynchus keta is characterized by a high protein and lipid composition in terms of dry substances. The carbohydrate part calculated by us by subtracting the protein, lipid and mineral parts is of interest for further research. The lipid fraction is of the greatest interest in the structure of the chemical composition of the by-products from the cutting of jacks, since its high content makes it difficult to store and process this by-products.

The results of the study of the fatty acid composition are presented in Table 4.

Table 4. Fatty acid composition of by-products from punching the roe of the chum salmon Oncorhynchus keta

\begin{tabular}{|c|c|}
\hline Fatty acid & Indicator \\
\hline $12: 0$ & 0.17 \\
\hline $14: 0$ & 3.40 \\
\hline i-15:0 & 0.10 \\
\hline $15: 0$ & 0.41 \\
\hline $16: 0$ & 12.28 \\
\hline i-17:0 & 0.21 \\
\hline ai-17:0 & 0.12 \\
\hline $17: 0$ & 0.33 \\
\hline i-18:0 & 0.22 \\
\hline $18: 0$ & 4.11 \\
\hline $20: 0$ & 0.17 \\
\hline Saturated & 21.52 \\
\hline $16: 1 n-7$ & 5.86 \\
\hline $16: 1 n-5$ & 0.26 \\
\hline $18: 1 n-9$ & 19.41 \\
\hline $18: 1 \mathrm{n}-7$ & 3.09 \\
\hline $18: 1 n-5$ & 0.79 \\
\hline $19: 1 n-9$ & 0.20 \\
\hline $20: 1 n-11$ & 0.35 \\
\hline $20: 1 n-9$ & 1.04 \\
\hline $20: 1 \mathrm{n}-7$ & 0.33 \\
\hline $22: 1 n-11$ & 0.51 \\
\hline $22: 1 n-9$ & 0.26 \\
\hline Monounsaturated & 32.10 \\
\hline $16: 2 n-4$ & 1.12 \\
\hline $16: 3 n-3$ & 0.54 \\
\hline $18: 2 n-9$ & 0.16 \\
\hline $18: 2 n-6$ & 1.35 \\
\hline $18: 2 n-4$ & 0.17 \\
\hline $18: 3 n-6$ & 0.21 \\
\hline $18: 3 n-3$ & 0.71 \\
\hline
\end{tabular}




\begin{tabular}{|c|c|}
\hline $18: 4 \mathrm{n}-3$ & 0.55 \\
\hline $18: 4 \mathrm{n}-1$ & 0.20 \\
\hline $19: 4 \mathrm{n}-3$ & 0.22 \\
\hline $20: 4 \mathrm{n}-6$ & 1.25 \\
\hline $20: 3 \mathrm{n}-3$ & 0.12 \\
\hline $20: 4 \mathrm{n}-3$ & 1.46 \\
\hline $21: 5 \mathrm{n}-3$ & $\mathbf{1 2 . 3 9}$ \\
\hline $22: 4 \mathrm{n}-6$ & 0.21 \\
\hline $22: 5 \mathrm{n}-3$ & 0.18 \\
\hline $\mathbf{2 0 : 5} \mathbf{n - 3}$ (Eicosapentaenoic Acid) & 4.74 \\
\hline $\mathbf{2 2 : 6}$ n-3 (Docosahexaenoic acid) & $\mathbf{2 0 . 2 9}$ \\
\hline Poliunsaturated & $\mathbf{4 5 . 8 7}$ \\
\hline Amount n-3 & $\mathbf{4 1 . 2 3}$ \\
\hline Amount n-6 & $\mathbf{2 . 9 9}$ \\
\hline The total of Eicosapentaenoic and Docosahexaenoic acids & $\mathbf{3 2 . 6 8}$ \\
\hline
\end{tabular}

It is worth noting the predominance of polyunsaturated fatty acids in the composition of by-products from punching the roe of the chum salmon, the share of which was $45.87 \%$. Among the saturated fatty acids, palmitic acid prevails, the content of which is more than half of the total of all saturated fatty acids. Among the monounsaturated fatty acids, oleic fatty acid prevails, the content of which is also more than half of all monounsaturated fatty acids. The high content of n-3 fatty acids, as well as the sum of EPA and DHA, allows us to consider the waste from the cutting of hawks as a valuable raw material.

\section{Conclusions}

The results of the conducted analytical and experimental studies indicate a high technological potential of by-products formed during the processing of crabs and in the production of salted caviar from salmon fish. The analysis of the chemical composition of the studied secondary raw materials proves the feasibility of its use for the production of biologically valuable feed and food products.

\section{References}

1. F. Al Khawli, F. J. Martí-Quijal, E. Ferrer, M. J. Ruiz, H. Berrada, M. Gavahian, et al. Aquaculture and its by-products as a source of nutrients and bioactive compounds. Advances in Food \& Nutrition Research, 1-33 (2020)

2. ARRUDA, Lia Ferraz de; BORGHESI, Ricardo and OETTERER, Marília. Use of fish waste as silage: a review. Braz. arch. biol. technol. [online]. vol.50, n.5 [cited 2021-04-29],pp.879-886.Availablefrom:<http://www.scielo.br/scielo.php?script =sci_arttext\&pid=S1516-89132007000500016\&lng=en\&nrm=iso>. ISSN 1678-4324. https://doi.org/10.1590/S1516-89132007000500016. (2007)

3. M. Espe, H. Haaland, L. R. Njaa. Autolysed fish silage a feed ingredient for Atlantic Salmon (Salmo salar). Composition Biochemistry Physiology, 103, 369-372 (1992)

4. M.D. Ristic, S.S. Filipovic, M.L.J. Sakac. Liquid protein feedstuffs from freshwater fish by-products as a component of animal feed. Romanian Biotechnological Letters, 7, 729-736 (2002)

5. J. N.Tatterson, M. L. Windsor. Fish silage. Journal of Science Food and Agriculture, 25, 369-379 (1974). 
6. C. Y. Lin, R. J. Li. Engine Performance And Emission Characteristics of Marine Fish-Oil Biodiesel Produced From The Discarded Parts of Marine Fish, Fuel Processing Technology. 90, 883 - 888 (2009)

7. P.S. Moraes, J.I. Engelmann, A.V. Igansi, T.R. Sant'Anna Cadaval Jr, Antonio de Almeida Pinto L. Nile tilapia industrialization waste: Evaluation of the yield, quality and cost of the biodiesel production process. Journal of Cleaner Production, V. 287 (2021)

8. García-Moreno, Pedro \& Khanum, Mohriam \& Guadix, Antonio \& Guadix, Emilia. Optimization of biodiesel production from waste fish oil. Renewable Energy. 68. 618624. 10.1016/j.renene. 03.014 (2014).

9. Tomczak-Wandzel, R., Levlin, E., Ekengren, Ö. \& Baresel, C. Biogas production from fish wastes in co-digestion with sewage sludge IWA Specialist Conference Holistic Sludge Management 6-8 May Västerås Sweden (2013).

10. M. Eiroa, JC. Costa, MM. Alves, C. Kennes, MC. Veiga. Evaluation of the biomethane potential of solid fish waste. Waste Manage. 32:1347-52 (2012).

11. T.H. Silva, J.Moreira-Silva, A.L. Marques, A. Domingues, Y. Bayon, R.L. Reis. Marine origin collagens and its potential applications. Mar. Drugs. 12, 5881-5901 (2014)

12. A.M. Ferreira, P. Gentile; V. Chiono, G. Ciardelli. Collagen for bone tissue regeneration. Acta Biomater. 8, 3191-3200 (2012).

13. H.J. Yoon, S.R. Shin, J.M. Cha, S.-H. Lee, J.-H. Kim, J.T. Do, H. Song, H. Bae. Cold water fish gelatin methacryloyl hydrogel for tissue engineering application. PLoS ONE, 11(2016)

14. E. Zelechowska, M. Sadowska, M. Turk. Isolation and some properties of collagen from the backbone of Baltic cod (Gadus morhua). Food Hydrocoll. 2010, 24, 325-329.

15. R. Ahmed, M. Haq, B.-S. Chun. Characterization of marine derived collagen extracted from the by-products of bigeye tuna (Thunnus obesus). Int. J. Biol. Macromol. 135, 668-676 (2019)

16. F. Guérard, L.Dufossé, D. De La Broise, A.Binet. Enzymatic hydrolysis of proteins from yellowfin tuna (Thunnus albacares) wastes using Alcalase. J. Mol. Catal. BEnzym. 11, 1051-1059 (2001)

17. Bhaskar, N., Benila, T., Radha, C., Lalitha, R.G.: Optmization of enzymatic hydrolysis of visceral waste protein of Catla (Catla catla) for preparing protein hydrolysate using a commercial pro-tease. Bioresour. Technol. 99, 335-343 (2007)

18. V.M. Silva, K.J. Park, M.D.Hubinger. Optimization of the enzymatic hydrolysis of mussel meat. J. Food Sci. 75(1), C36-42 (2010)

19. N. M. Kupina, S. V. Levankov. The use of waste from the cutting of crabs / Fish farming. Issue 4. p. 56 (1998) 